\title{
STUDY OF AWARENESS AND USE OF WEB RESOURCES BY THE RESEARCHERS OF INDIAN VETERINARY RESEARCH INSTITUTE (IVRI), IZZATNAGAR, BAREILLY
}

\author{
Divya Pandey \\ Assistant Professor \\ Department of Library and Information Science \\ Sahu Ram Swaroop Mahila Mahavidyalaya Bareilly (U.P), India
}

\begin{abstract}
Manuscript Info
Manuscript History

Received: 08 December 2020

Final Accepted: 22 January 2021

Published: 10 February 2021

Online Published: March 2021

DOI: http://dx.doi.org/10.35337/EIJLITR.2021.1301

(C) Divya Pandey The Author. This is an open access article under the terms of the Creative Commons Attribution License 4.0, which allows use, distribution and reproduction in any medium, provided the original work is properly cited.
\end{abstract}

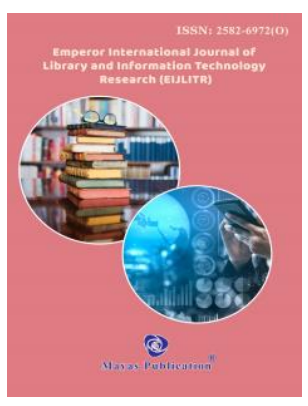

\section{Abstract}

The primary motive of the present paper is to explain the level of awareness and use of Web Resources by the researchers of Indian Veterinary Research Institute (I.V.R.I), Izzatnagar, Bareilly, (U.P), India. Further the main purpose of this study is to focus the problem faced by the researchers of I.V.R.I, while retrieving the Web Resources. The data required for the study was collected through a well structured questionnaire. A total no. of 50 filled questionnaires was return back from the researches. Current study displays that the Web Resources were very useful for the researchers of I.V.R.I for their regular research work or any other purpose and Google is the widely used search engine in the I.V.R.I. Popular publishers E-Journal database consulted by the researchers were PUB-MED and Science Direct. Further the study also examines the use, importance, reliability and satisfaction on Web Resources over Print Resources.

Key Words - Awareness, Use, Web Resources, Researchers, IVRI, E-books, E-journals, Websites, Problem, Questionnaire.

\section{INTRODUCTION}

Modern era is the era of Information Technology, where Information is the most important commodity for the development of any country or society. If it is said that at present man is becoming completely dependent on Technology, then there will be no exaggeration. Because at present technology is being used in all fields of life like Business, Industry, Engineering, Office, Education etc. And no field of life is now untouched by technology. Even a person used technology to carry out their daily activities.

Today Information is delivered digitally via Internet or World Wide Web (WWW). It is necessary to understand Information Technology before understanding Web Resources, because Web Resources are the part of Information Technology. As its name implies, web resources are the resources that can be 
obtained via website or internet. Web Resources are also known as Electronic Information Resources and Digital Resources. We use different types of web resources such as E-books, E-journals, E-newspapers, Emagazines, Website, Search Engines etc in our study, teaching, research and any other works.

\section{Objectives of the study}

The present study has been done with some objectives in mind, which are as follow-

$>$ Finding the way for searching and obtaining the Web Resources.

$>$ Identify the influence of Web Resources on the efficiency of researchers.

$>$ To recognize the mode of searching adopted by the researchers to locate the Web Resources.

$>$ To recognize the particular Web Resources (E-references, E-journals, Search engines, Websites, Ebooks etc.) consulted by the researchers.

$>$ Determining how much researchers are satisfied with the use of Web Resources.

$>$ Finding the problem faced by the researchers while using the Web Resources.

\section{Scope of the study}

This study focuses on the reliability and uses of Web Resources by the researchers of various departments of I.V.R.I, Izzatnagar, Bareilly, U.P, India. It is also highlights the present scenario in web resources or electronic information resources supporting the research programmes in Indian Veterinary Research Institute.

\section{Research Methodology}

Survey methodology is used by the researcher to collect the data in the present study. Questionnaire was used by the researcher for collecting data from the researchers of various departments of I.V.R.I. All 50 filled questionnaires were return back from the researchers of IVRI, Izzatnagar, Bareilly. The data received through questionnaire is presented in the form of tables and figures.

\section{TABLE 1}

\section{WEB RESOURCES AWARENESS}

\begin{tabular}{|c|c|c|}
\hline Awareness & No. of responses & Percentage \\
\hline Yes & 50 & $100 \%$ \\
\hline No & - & - \\
\hline
\end{tabular}

The data presents in table 1 shows that responses on awareness of web resources revealed that $50(100 \%)$ of the researchers of I.V.R.I. are aware of web resources and are using them.

The data presented in table number 1 may be graphically represented as given in figure no. 1

FIGURE 1

WEB RESOURCES AWARENESS

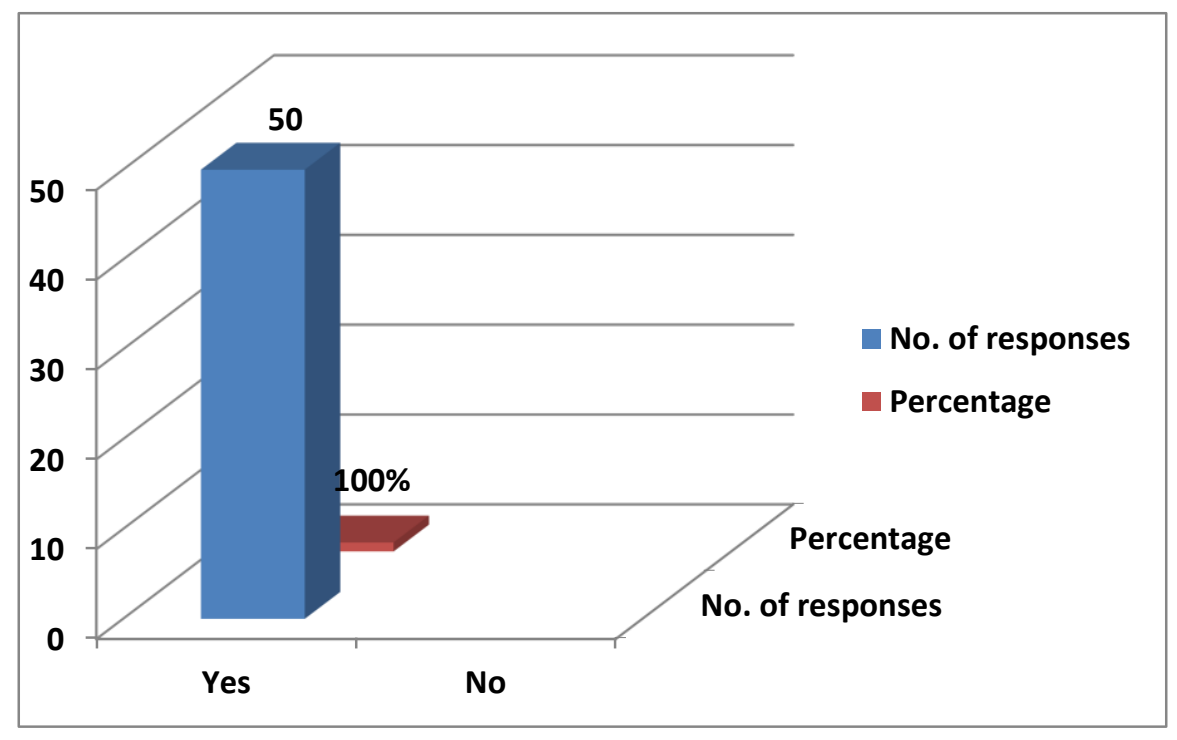


TABLE 2

USAGE OF WEB RESOURCES

\begin{tabular}{|l|l|l|}
\hline Use & No. of responses & percentage \\
\hline Yes & 50 & $100 \%$ \\
\hline No & - & - \\
\hline
\end{tabular}

The data presented in table 2. Shows that responses on using of web resources revealed that $50(100 \%)$ of the researchers of I.V.R.I are using the web resources.

The data presented in table number 2 may be graphically represented as given in figure no. 2

FIGURE 2

\section{USAGE OF WEB RESOURCE}

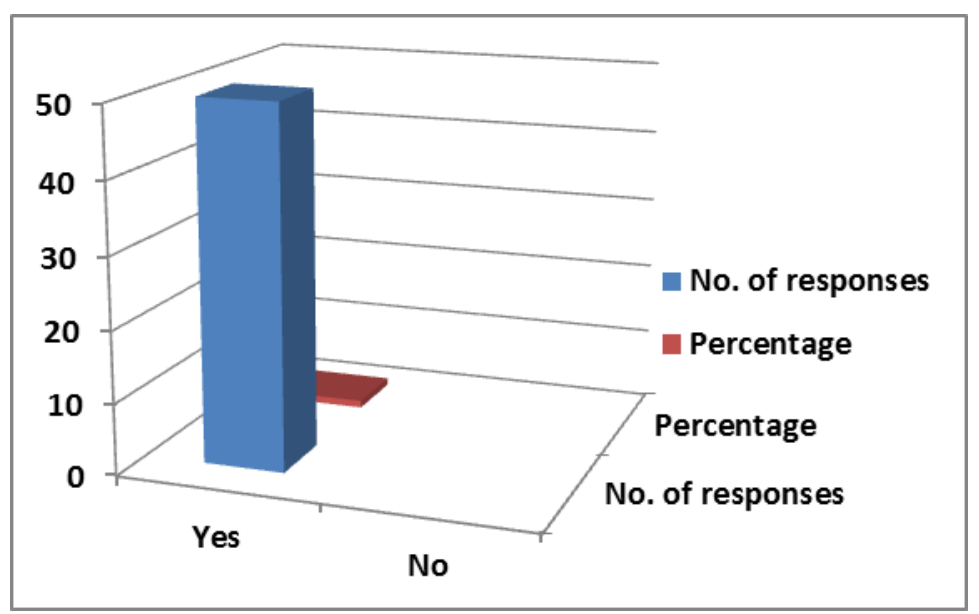

TABLE 3

PURPOSE OF USING WEB RESOURCE

\begin{tabular}{|l|c|c|}
\hline Purpose & No. of respondents & Percentage \\
\hline Study and Research & 48 & $96 \%$ \\
\hline Improving Knowledge & 23 & $46 \%$ \\
\hline Career development & 15 & $30 \%$ \\
\hline Any other & 4 & $8 \%$ \\
\hline
\end{tabular}

Table no. 3 reveals that plurality of the total researchers i.e. 48 (96\%) use web resources for study and research, 23(46\%) users use the web resources for improving knowledge, while 15(30\%) of the users use it for career development and the only $4(8 \%)$ of the researchers use web resources for any other work. The data presented in table number 3 may be graphically represented as given in figure 3

FIGURE 3

PURPOSE OF USING WEB RESOURCE

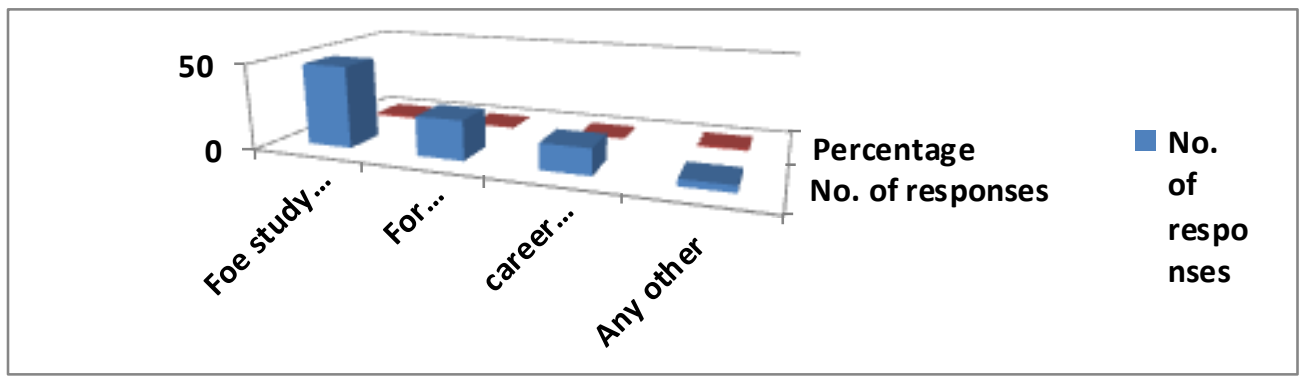


TABLE 4

FREQUENCY OF USING WEB RESOURCES

\begin{tabular}{|l|c|c|}
\hline Frequency & No. of respondents & Percentage \\
\hline Daily & 49 & $98 \%$ \\
\hline Weekly & - & - \\
\hline Monthly & - & - \\
\hline Occasionally & 1 & $2 \%$ \\
\hline
\end{tabular}

It is observed from the table number 4 that a majority of the total respondents i.e. $49(98 \%)$ are using the web resources daily and the only few $1(2 \%)$ of the researchers using the web resources occasionally.

The data presented in table number 4 may be graphically represented as given in figure no. 4

FIGURE 4

FREQUENCY OF USING WEB RESOURCES

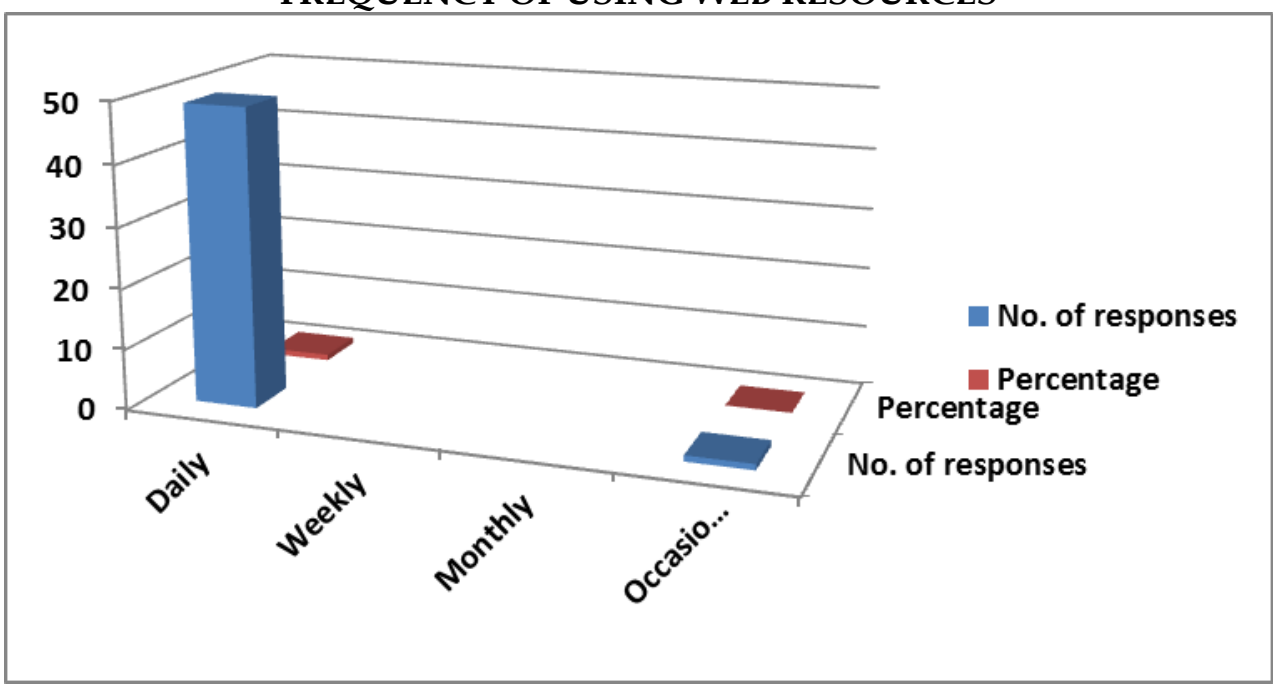

TABLE 5

PLACE OF ACCESSING OF WEB RESOURCES

\begin{tabular}{|l|c|c|}
\hline Place of access & No. of Responses & Percentage \\
\hline Central Library & 26 & $52 \%$ \\
\hline Department Lab & 38 & $76 \%$ \\
\hline Computer Centre & 3 & $6 \%$ \\
\hline Cyber Café & - & - \\
\hline Any Other & 14 & $28 \%$ \\
\hline
\end{tabular}

It is cleared from table number 5 that the majority of the researchers $38(76 \%)$ access Web resources in Department Lab, 26(52\%) researchers use it from the Central Library, 14(28\%) of the researchers using the Web resources from Any other source and only $3(6 \%)$ of the researchers using the Web resources from Computer centre. It is noteworthy that none of the respondent uses Cyber Café for accessing Web resources.

The data presented in table number 5 may be graphically represented as given in figure no. 5 
FIGURE 5

PLACE OF ACCESSING WEB RESOURCES

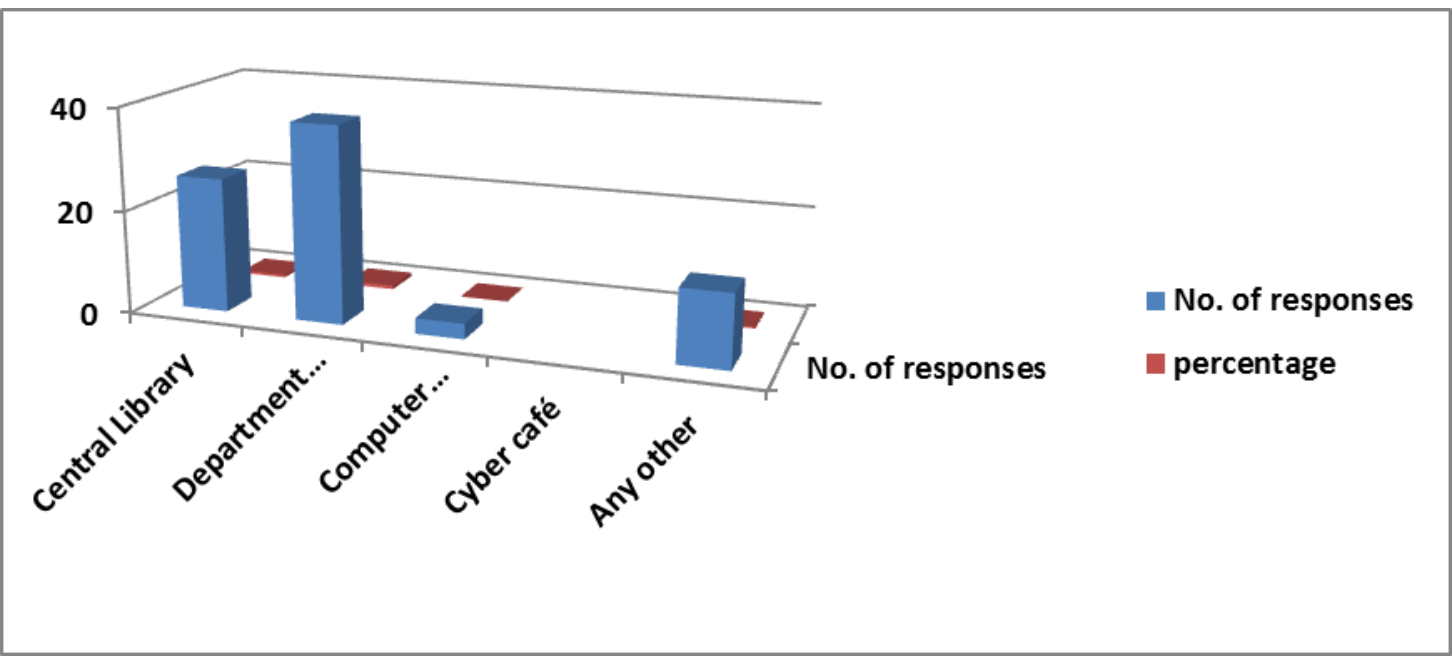

TABLE 6

RELIABILITY OF WEB RESOURCES

\begin{tabular}{|l|c|c|}
\hline Reliability & No. of responses & Percentage \\
\hline Reliable & 41 & $82 \%$ \\
\hline Unreliable & - & - \\
\hline Not sure & 9 & $18 \%$ \\
\hline
\end{tabular}

The table number 6 shows that $41(82 \%)$ of the researchers found the Web resources reliable while $9(18 \%)$ researchers are not sure of the reliability of Web resources.

The data presented in table number 6 may be graphically represented as given in figure no. 6

FIGURE 6

RELIABILITY OF WEB RESOURCE

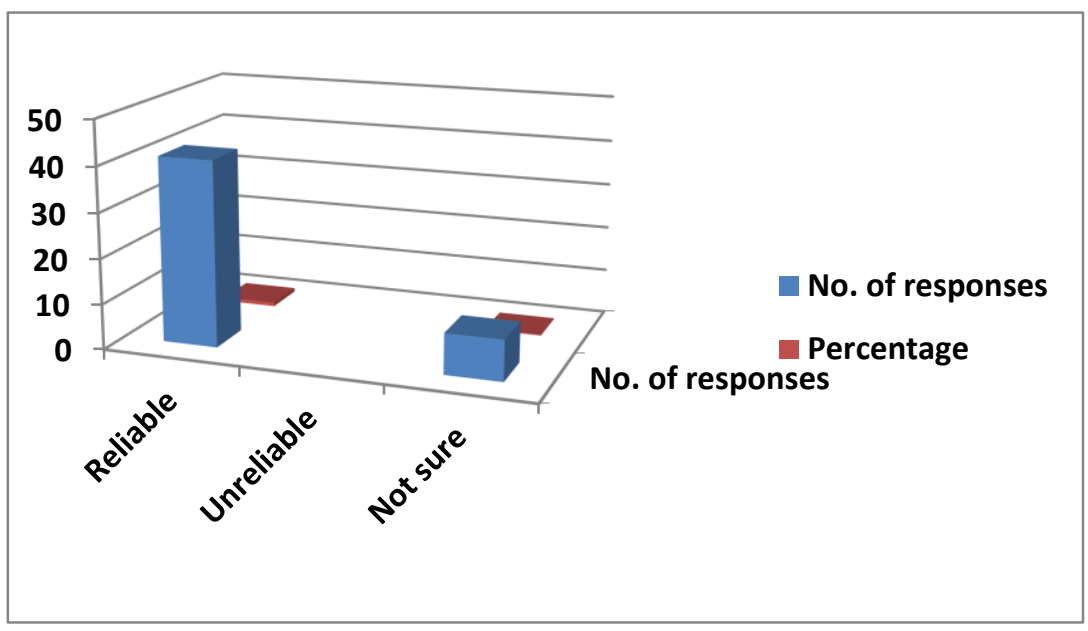

TABLE 7

MODE OF ACCESSING OF WEB RESOURCES

\begin{tabular}{|l|c|c|}
\hline \multicolumn{1}{|c|}{ Mode of access } & No. of responses & Percentage \\
\hline Links through Library Websites & 6 & $12 \%$ \\
\hline Links through Publisher Website & 7 & $14 \%$ \\
\hline Links through On line journals Website & 21 & $42 \%$ \\
\hline Links through Search Engine & 33 & $66 \%$ \\
\hline Any Other & 4 & $8 \%$ \\
\hline
\end{tabular}


The table number 7 clearly depicts that $33(66 \%)$ of the respondents accessing the Web resources through Search engine, 21 (42\%) researchers search and access the Web resources by links through on line journals Web site, $7(14 \%)$ researchers used links through Publisher website, 6(12\%) used links through Library website, while $4(8 \%)$ of the researchers search and access the Web resources by any other mode.

The data presented in Table number 3 may be graphically represented as given in figure 7

FIGURE 7

MODE OF ACCESSING OF WEB RESOURCES

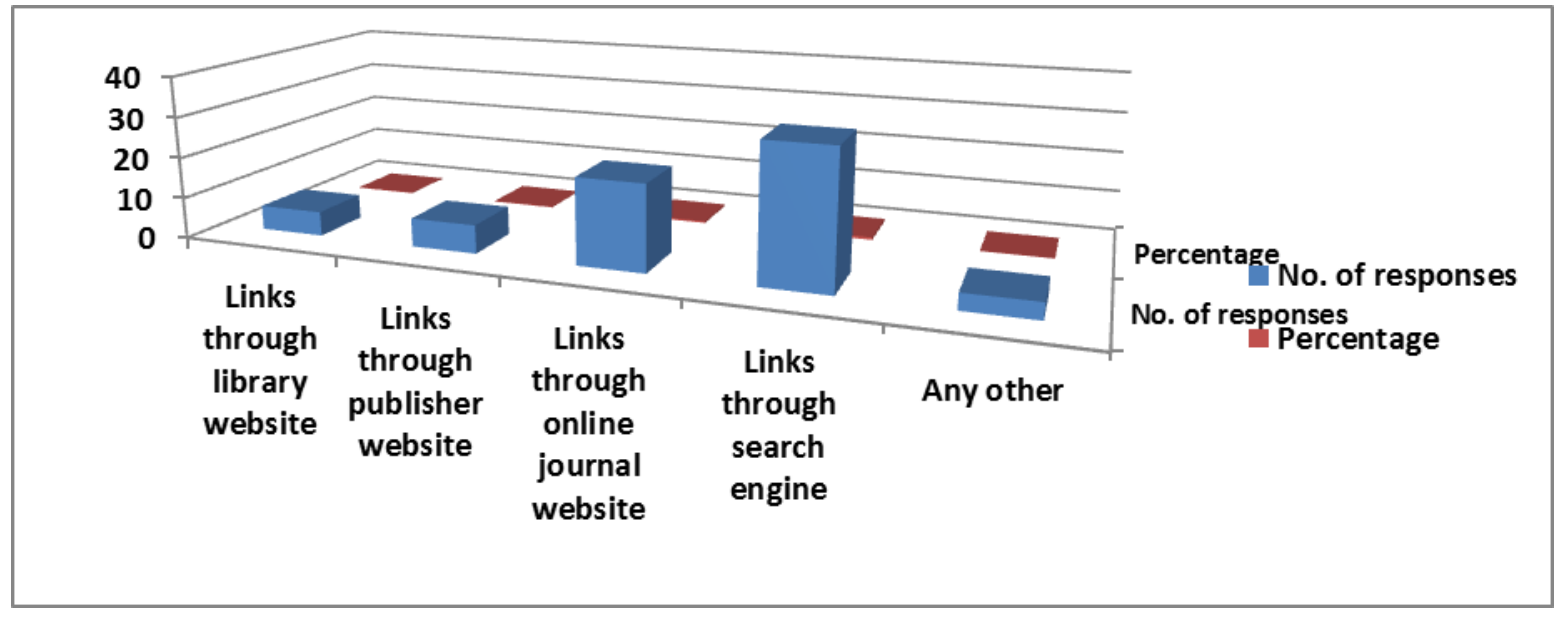

TABLE 8

SATISFACTION LEVEL WITH THE USE OF WEB RESOURCES

\begin{tabular}{|l|c|c|}
\hline Satisfaction Level & No. of Responses & Percentage \\
\hline Partially Satisfied & 9 & $18 \%$ \\
\hline Fully Satisfied & 8 & $16 \%$ \\
\hline Satisfied & 34 & $68 \%$ \\
\hline Dissatisfied & - & - \\
\hline
\end{tabular}

The analysis of Table 8 clearly shows that majority of researchers 34(68\%) are satisfied with the use of Web resources, while $9(18 \%)$ of them are partially satisfied, another $8(16 \%)$ are fully satisfied with the use of Web resources.

The data presented in table number 9 may be graphically represented as given in figure no. 8

FIGURE 8

SATISFACTION LEVEL WITH THE USE OF WEB RESOURCE

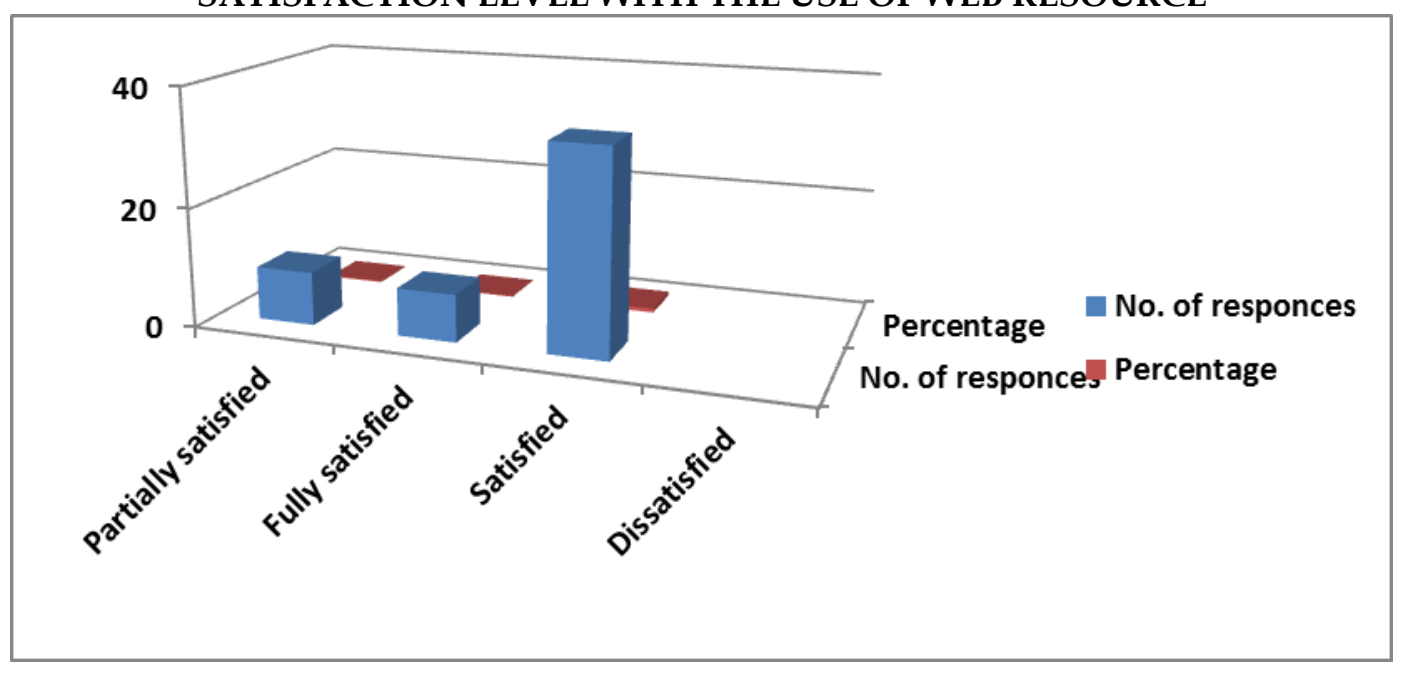


TABLE 9

BARRIERS WHILE USING WEB RESOURCE

\begin{tabular}{|l|c|c|}
\hline \multicolumn{1}{|c|}{ Barriers } & No. of Responses & Percentage \\
\hline Too much information retrieved & 20 & $40 \%$ \\
\hline Time consuming/ Slow speed & 16 & $32 \%$ \\
\hline Lack of IT(information technology) knowledge & 6 & $12 \%$ \\
\hline Limited access to computer terminals & 1 & $2 \%$ \\
\hline
\end{tabular}

Table 9 shows that $20(40 \%)$ researchers find that due to information explosion too much information is available on each topic, and it is very difficult to retrieve the required information from this ocean of information, while 16(32\%) researchers face slow speed as barrier for using Web resources, 6(12\%) researchers has lack of IT (Information Technology) knowledge and 1(2\%) researchers find limited access to computer terminals.

The data presented in table 10 may be graphically represented as given in figure no. 9

\section{FIGURE 9}

BARRIERS WHILE USING WEB RESOURCES

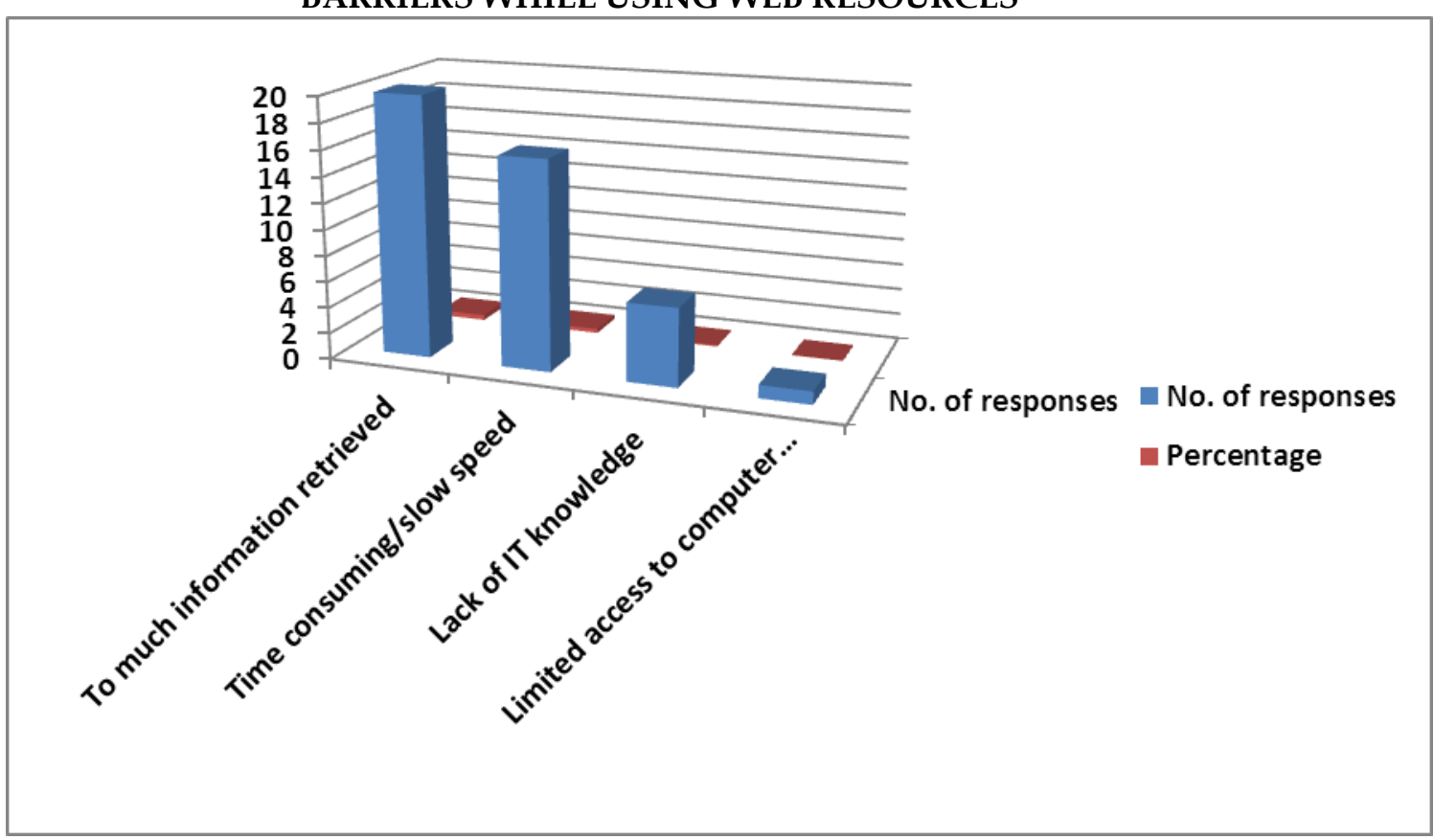

TABLE10

PREFERENCE OF USING WEB RESOURCES

\begin{tabular}{|l|c|c|}
\hline Search Engines & No. of Responses & Percentage \\
\hline Google & 50 & $100 \%$ \\
\hline Alta Vista & - & - \\
\hline Yahoo & 2 & $4 \%$ \\
\hline Any Other & - & - \\
\hline
\end{tabular}

Table number 10 shows that 50(100\%) researchers confirms that they prefer to use Google as a search engine and 2(4\%) researchers prefer to use Yahoo and no one researcher prefer to use Alta Vista and any other Search Engine.

The data presented in table 4 may be graphically represented as given in figure no. 10 
FIGURE 10

PREFERENCE OF USING WEB RESOURCES

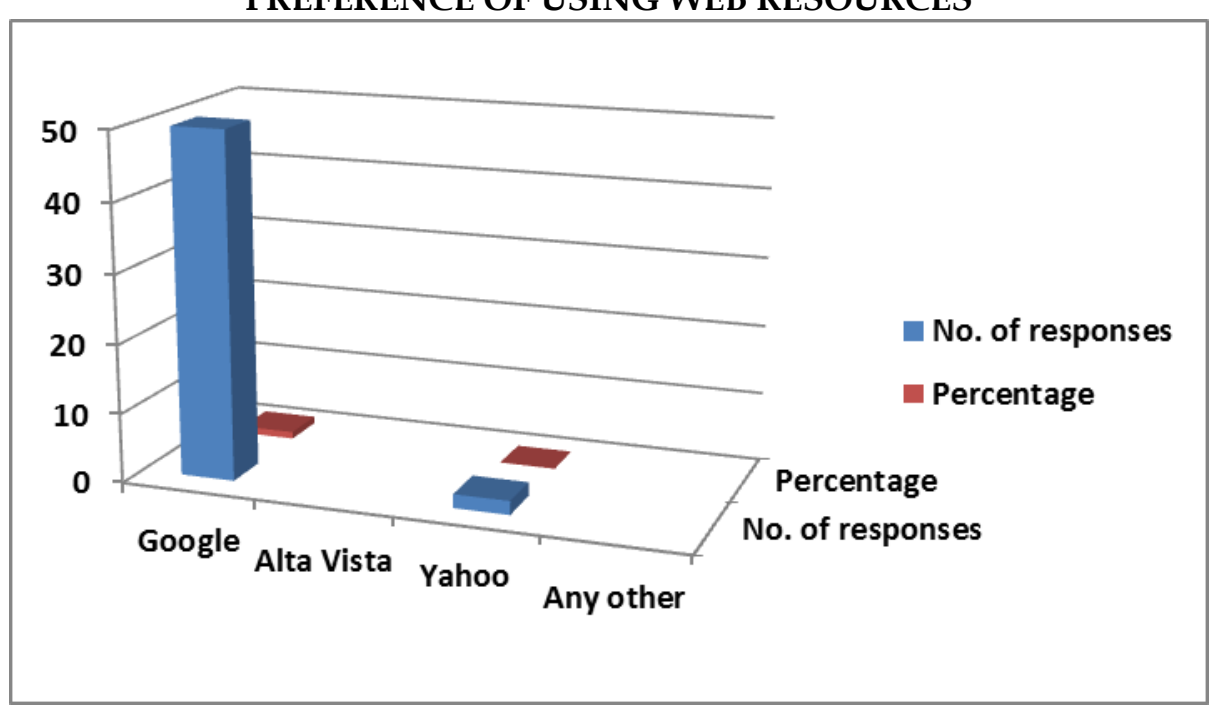

TABLE 11

E-JOURNAL DATABASE CONSULTED BY RESEARCHERS

\begin{tabular}{|l|c|c|}
\hline E-journals publishers & No. of Responses & Percentage \\
\hline Pub-Med & 38 & $76 \%$ \\
\hline Science Direct & 25 & $50 \%$ \\
\hline J-Gate & 6 & $12 \%$ \\
\hline Any Other & - & - \\
\hline
\end{tabular}

Table number 11 presents that 38(76\%) researchers consulted Pub-Med E-journal database, 25(50\%) researchers use Science Direct and 6(12\%) researchers consulted J-Gate E-journal database.

The data presented in table 13 may be graphically represented given as figure no. 11.

Figure 11

E-journal databases consulted by researchers

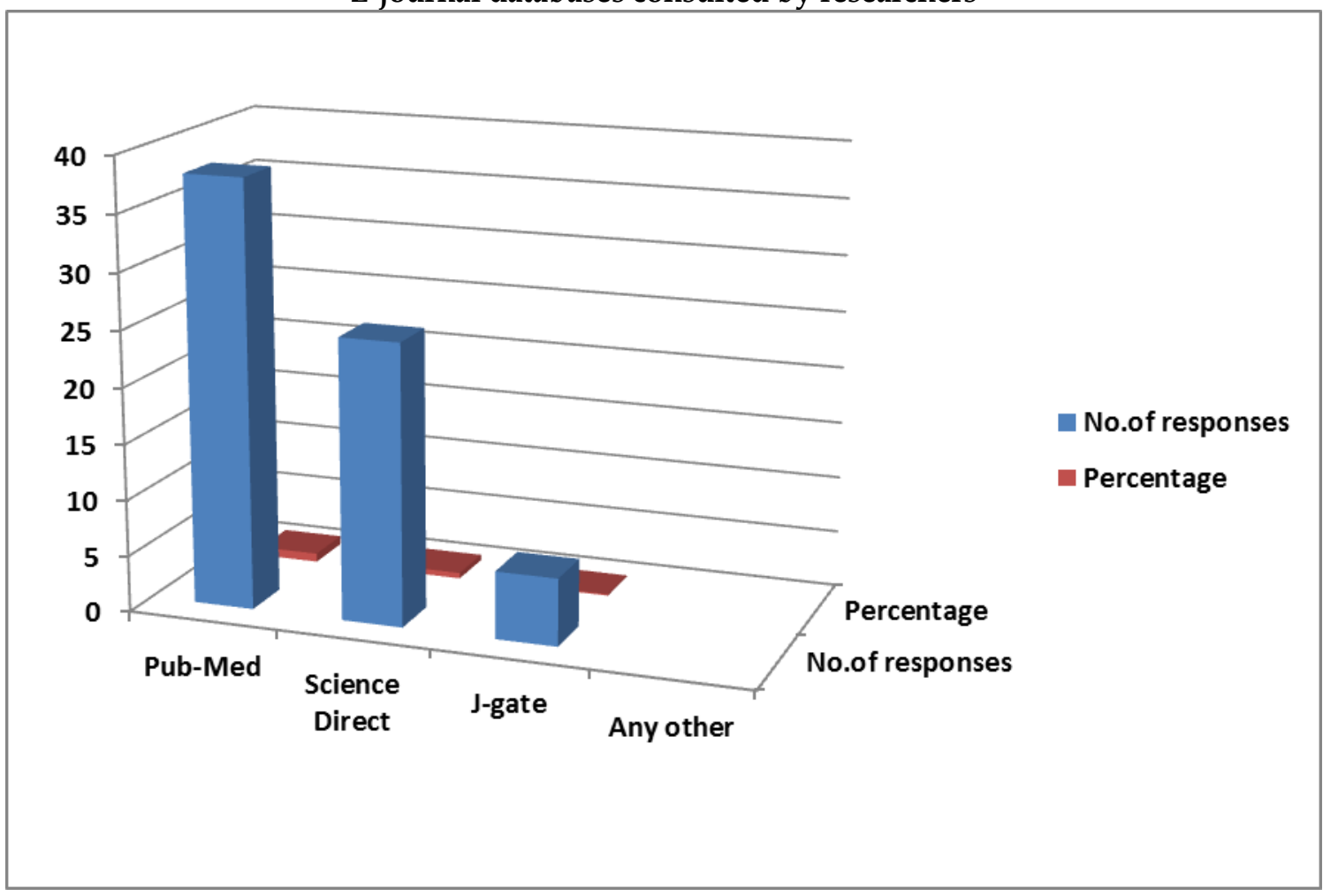


TABLE 12

MODE OF SEARCHING OF WEB RESOURCES

\begin{tabular}{|l|c|c|}
\hline Mode of searching & No. of Responses & Percentage \\
\hline Keyword & 40 & $80 \%$ \\
\hline Boolean Logic & - & - \\
\hline Field Search & 13 & $26 \%$ \\
\hline Phrase Search & 6 & $12 \%$ \\
\hline
\end{tabular}

Table number 12 shows that $40(80 \%)$ researchers search their retrieved information through keyword searching, $13(26 \%)$ researchers retrieved the information through field search, while $6(12 \%)$ of the researchers retrieved the information through phrase search.

The data presented in table 12 may be graphically represented as given in figure no. 12

FIGURE 12

MODE OF SEARCHING OF WEB RESOURCES

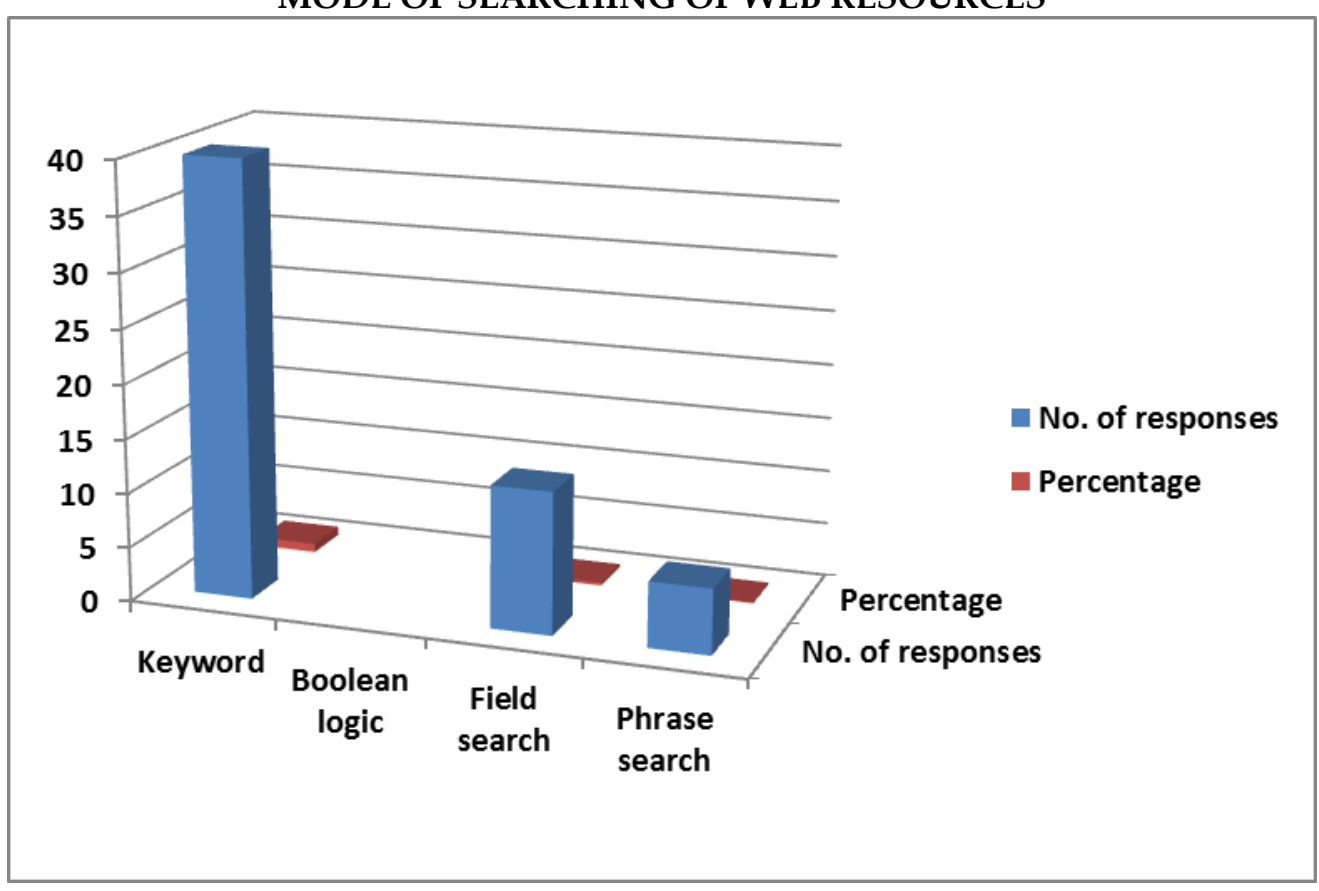

TABLE 13

E-BOOKS USED BY THE RESEARCHERS

\begin{tabular}{|l|c|c|}
\hline E-books usage & No. of Responses & Percentage \\
\hline Yes & 24 & $48 \%$ \\
\hline No & - & - \\
\hline
\end{tabular}

Table number 13 shows that $24(48 \%)$ researchers consulted the E-books for their research work.

The data presented in table 16 may be graphically represented as given in figure no. 13 
FIGURE 13

E-BOOKS USED BY RESEARCHERS

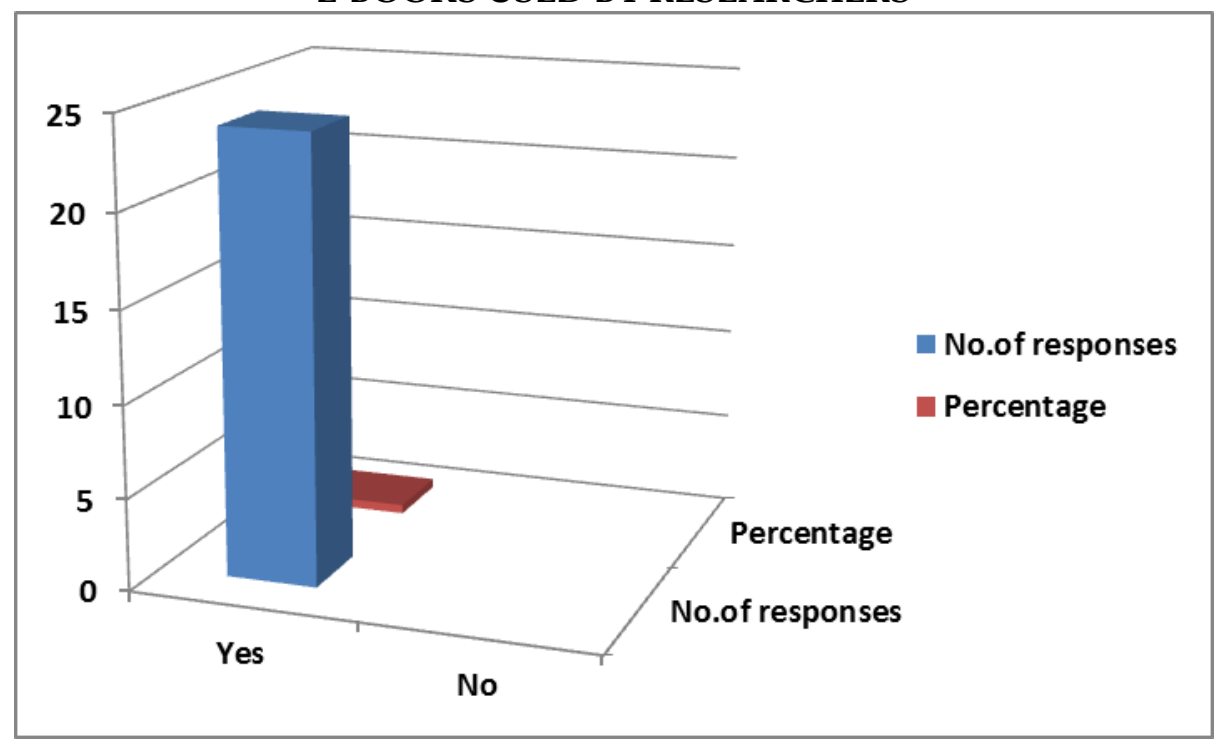

\section{Suggestions}

$>$ Time to time institute should organise workshops related to the effectual use of Web Resources.

$>$ Researcher should be provided with $24 \times 7$ high speed internet connectivity for efficient and favourable utilization of web resource.

> For I.V.R.I researchers, the highest speed internet facility should be provided in the Institute itself, so that they do not face any problem in the use of Web Resources.

$>$ Suggestions from the various departments of I.V.R.I should be taken time to time for improvement in web resources services.

$>$ Library staff should also be fully aware of the use of Web Resources, so that they can cooperate fully to help researchers in case of any kind of problem.

$>$ Library should increase the number of Web Resources in different subjects.

7-Search tool mostly used by the researchers for searching are search engine so search engines and on-line facilities must be provided to them in the institute.

\section{CONCLUSION}

After studying the entire paper, it finally concludes that at the present time Web Resources are very important because now a days almost everything is available on the web.

Web resources are an essential part of the research work in I.V.R.I and majority of the researchers were using the web resources for their study and research, Web Resources are also known as Digital Resources and Electronic Information Resources. E-journals, E-books, E-newspapers, On-line courses, On-line database, Chat, Mailing list, Web links, On-line book shop, Sound etc. These web resources are very essential for the researchers for their research work, study and upgrading their knowledge.

This study suggest that the high speed internet facility should be provided to the researchers with $24^{*} 7$ in the institute, because without internet facility researchers can not access the web resources such as Ejournals, E-newspaper, E-references, Search engines, Websites etc.

At the last we can say that the present study will be useful for future researchers for their research field and any other purpose.

\footnotetext{
About the author

The author is presently working as an Assistant Professor in the department of Library and Information Science in Sahu Ram Swaroop Mahila Mahavidyalaya Bareilly. She did B.com, B.lib.ISc. From Bareilly college Bareilly and also obtained her master degree in Library and Information Science from the same college. She has also qualified UGC NET in 2018.
} 


\section{REFERENCE}

1. Abdullah, N and Gibb F. (2006). A survey of e-books awareness and usage amongst student in an academic library. Proceedings of international conference of multidisciplinary information science and technology, 2006

2. E-newspaper. (Retrieved on 6/5/17) https://en.m.wikipedia.org

3. E-references. (Retrieved on 6/5/17) https://llibguides.ubd.edu.bn/content_mobile.php?pid470717

4. Search Engine. (Retrieved on 6/5/17) https://designhammer.com>seo-guide

5. Sohail, MD and Alvi, Andleeb (2014). Use of web resources by medical science students of Aligarh Muslim University. DESIDOC journal of library and information technology, 2014. 34(2), 125-130p.

6. Thansukodi, S. (2011). User awareness and use of on line journals among Education Faculty members in Coimbatore district: a survey. J communication, 2011. 2(1), 23-32p.

7. Website. (Retrieved on 6/5/17) dictionary.cambridge.org>dictionary

8. Zaidi, Mohamad Musthafa. K (2012). Use of web resources for scholary research in language and literature: a study among research scholars in Aligarh Muslim University, India. International research: journal of library and information science, 2012. 2(1), 25-45p. 